МОТИВАЦІЙНО-ЦІННІСНІ ЗАСАДИ ФОРМУВАННЯ ГОТОВНОСТІ МАЙБУТНІХ ПЕДАГОГІВ ДОШКІЛЬНОЇ ОСВІТИ ДО ЗАСТОСУВАННЯ STЕМ-ТЕХНОЛОГІЙ У ПРОФЕСІЙНІЙ ДІЯЛЬНОСТІ

\title{
MOTIVATIONAL-VALUE FOUNDATIONS OF THE FORMATION OF FUTURE PRESCHOOL EDUCATION TEACHERS' READINESS TO USING STEM TECHNOLOGIES IN PROFESSIONAL ACTIVITY
}

Статтю присвячено одній 3 актуальних проблем професійної підготовки майбутніх педагогів закладів дошкільної освіти - мотиваційно-ціннісним засадам формування готовності до застосування STEM-технологій у професіійній діяльності. Зокрема, розкрито сутність таких понять, як: «готовність майбутніх фрахівців дошкільної освіти до профресійної діяльності», «фрормування готовності майбутніх педагогів дошкільної освіти до застосування STEM-технологій у профресійній діяльності».

3 огляду на теорію вмотивованості суб'єкта до перетворення об'єктів своєі діяльності з новими властивостями та якостями, зосереджено увагу на мотиваційно-ціннісних засадах формування готовності майбутніх педагогів дошкільної освіти до застосування STEMтехнологій у профессійній діяльності. На основі аналізу наукового доробку про те, що мотивація є регулятором профресійно діяльності та впливає на їі продуктивність, провідним компонентом у структурі готовності майбутніх педагогів дошкільної освіти до застосування STEMтехнологій у профресійній діяльності виділено мотиваційно-ціннісний компонент. Обгрунтовано структуру мотиваційноціннісного компонента, а саме: ступінь сорормованості STEM-освітніх иіннісних орієнтацій; самоаналіз особистості 3 позиції STEM-діяльності; особистісний сенс STEM-діяльності.

У результаті проведеного анкетування визначено основні мотиви, які спонукають майбутніх педагогів дошкільної освіти до застосування STEM-технологій у професійній діяльності: розуміння перспектив саморозвитку в профресії; розвиток творчого мислення; інтелектуальний розвиток; підвищення професійної компетентності; мотив ігри і розваги; досягнення нових педагогічних цілей; соціальна відповідальність.

Окреслено перспективи подальших досліджень у напрямі обірунтування інших компонентів у структурі готовності майбутніх педагогів дошкільної освіти до застосування STEM-технологій у профресійній діяльності: когнітивного, діяльнісного і рефлексивного.
Ключові слова: заклади дошкільної освіти, майбутні педагоги, STEMтехнології, STEM-освіта, професійна підготовка.

The article is devoted to one of the urgent problems of professional training of the future teachers of preschool education institutions - motivational-value foundations of forming readiness for using STEM technologies in professional activity. In particular, the study reveals the essence of such concepts as: "readiness of future preschool education specialists for professional activity", "formation of future preschool education teachers' readiness for using STEM technologies in professional activity".

Given the theory of the subject's motivation for transforming the objects of their activities with new properties and qualities, it is focused on the motivational-value foundations of forming future preschool teachers' readiness to use STEM technologies in professional activities. Based on the analysis of scientific achievements that motivation is a regulator of professional activity and affects its productivity, the leading component in the structure of future preschool teach ers' readiness to using STEM technologies in professional activity is a motivational-value component. The structure of the motivationalvalue component is substantiated, namely: the degree of formation of STEM-educational value orientations; self-analysis of the personality from the standpoint of STEM activity; personal meaning of STEM activity.

As a result of the survey, the main motives that motivate future preschool education teachers to use STEM technologies in professional activity are identified: understanding the prospects of self-development in the profession; development of creative thinking; intellectual development; increase of professional competence; motive of game and entertainment; achievement of new pedagogical goals; social responsibility.

The prospects for further research are seen in substantiation of other components in the structure of future preschool teachers' readiness to use STEM technologies in professional activities: cognitive, activity and reflexive. Key words: preschool education institutions, future teachers, STEM technologies, STEM education, professional training.
Постановка проблеми у загальному вигляді. У сучасному розвитку суспільства спостерігаються важливі процеси, спрямовані на вдосконалення системи профресійної освіти.

Формування готовності майбутніх педагогів дошкільної освіти до застосування STEMтехнологій у професійній діяльності нині $€$ актуальним завданням, що стоїть перед закладами вищої педагогічної освіти.
Дослідження проблеми фрормування готовності до професійної діяльності неможливо здійснювати, не включивши систему активних відносин суб'єкта до об'єкта діяльності, які виражаються у мотивації профресійної діяльності. Домінантною стає підготовка фрахівця, який усвідомлює свою соціальну відповідальність за творчий розвиток особистості дитини, постійно дбає про особистісне і професійне зростання, вміє досягти нових педагогічних цілей. 
Аналіз останніх досліджень і публікацій. Сучасні дослідження провідних науковців розкривають різні аспекти готовності майбутніх педагогів дошкільної освіти. Зокрема, питання теорії та практики фрормування готовності фрахівців закладів дошкільної освіти досліджують: Г. Бєлєнька, А. Богуш, Н. Гавриш, К. Крутій, І. Луценко та інших.

Актуальність запровадження STEM-освіти у профресійній освіті обґрунтовано у роботах науковців О. Патрикеєвої, О. Лозової, С. Горбенко та інших.

Психолого-педагогічний аспект фрормування готовності студентів до розвитку професійних умінь майбутнього педагога у системі дошкільного виховання розглядається у працях: 3. Борисової, Л. Завгородньої, Є. Карпової, О. Кучерявого, Н. Лисенко, Г. Сухорукової та інших.

Проблема мотиваційної готовності є однією із головних у підготовці майбутнього педагога.

Нині держава відводить одну з провідних ролей мотивації навчальної та професійної діяльності. Це пов'язано з тим, що суспільство вимагає від людини активної життєвої позиції, усвідомленості своїх виборів, прийняття відповідальності за життєве самовизначення, готовність підвищувативласний особистісний і професійний рівень, ставити й уміти вирішувати завдання самовдосконалення.

Це сприяє більш якісній підготовці майбутніх фрахівців дошкільної освіти до професійної діяльності, яка потребує нині сорормованих ключових компетентностей концепції «Нової української школи», а саме математичної грамотності, компетентності в природничих науках і технологіях, інорормаційно-цифррової грамотності, уміння навчатися впродовж життя, соціальної й громадянської компетентності, підприємливості, загальнокультурної грамотності, екологічної грамотності і здорового життя, гармонійно входять у систему STEM-освіти, створюючи основу для успішної самореалізації особистості і як фрахівця, і як громадянина [6, с. 21].

Саме мотиваційний компонент навчання не лише забезпечує високі результати за умови безпосереднього педагогічного впливу, а гарантує пролонговану пізнавальну активність у будь-яких ситуаціях життєдіяльності [4, с. 68].

Виділення не вирішених раніше частин загальної проблеми. У результаті аналізу джерельної бази наукових досліджень з'ясовано, що проблема фрормування готовності майбутніх фрахівців дошкільної освіти до професійної діяльності засобами STEM-технологій залишається відкритою. Відсутні дидактичні і методичні аспекти розвитку мотивації та ціннісного ставлення до застосування STEM-технологій у дошкільній освіті.

Мета статті. Метою нашого дослідження було обґрунтування мотиваційно-ціннісних засад готовності майбутніх педагогів до застосування STEM- технологій у професійній діяльності та визначення основних мотивів, спрямованих на фрорсування позитивної мотивації майбутніх педагогів до STEM-освіти, які сприятимуть творчому професійному розвитку; з'ясування значення професійноціннісних орієнтацій, які забезпечують усвідомлену потребу оволодіння основами STEM-діяльності.

Виклад основного матеріалу. Вирішення проблеми формування мотиваційної готовності майбутніх педагогів до застосування STEM-технологій у профресійній діяльності потребує розкриття понять «професійна готовність» та «готовність майбутніх педагогів дошкільної освіти до застосування STEM-технологій у професійній діяльності».

Відповідно до сучасного тлумачного словника: «Готовність - стан, за якого все зроблено, все готово для чого-небудь» [10, с. 32].

А. Леонтьєв визначає готовність як процес формування певних умінь, які своєю чергою проходять такі етапи становлення: 1) процес, що спостерігається ззовні; 2) опанування способами діяльності; 3) готовність особистості самостійно виконувати дії [8, с. 274].

Формування готовності майбутніх фрахівців дошкільної освіти до профресійної діяльності - це накопичення знань, умінь і навичок практичної діяльності у галузі дошкільної освіти. Формування готовності майбутніх фрахівців до практичної роботи спрямоване на підготовку їх до раціональної і досконалої професійної діяльності 3 дітьми дошкільного віку. Від ступеня сорормованості готовності майбутніх фрахівців до подальшої професійної діяльності залежить успішність та ефрективність їх самореалізації у вибраній профресії фрахівця дошкільного освітнього закладу [9, с. 73].

Сучасний процес професійної підготовки майбутніх фрахівців дошкільної освіти ґрунтується на засадах STEM-освіти і використанні STEMтехнологій [3; 7].

Отже, формування готовності майбутніх педагогів дошкільної освіти до застосування STEMтехнологій у професійній діяльності ми розуміємо як інтегральну, профресійну й особистісну характеристику майбутнього педагога, що дає змогу забезпечити раціональну і досконалу профресійну діяльність із дітьми дошкільного віку, основою якої $€$ методологічна єдність природничих, технічних і соціально-гуманітарних наук, що проявляється у застосуванні спільного математичного апарату, інформаційно-комунікаційних технологій, моделювання та міждисциплінарної взаємодії.

Одним із найбільш важливих компонентів готовності до професійно-педагогічної діяльності окремі автори (В. Асєєв, А. Маркова, Дж. Олпорт та інші) виділяють мотиваційну готовність до пошуку і вирішення завдань за межами будь-якого зовнішнього контролю. 
Вітчизняні та зарубіжні вчені Л. Божович, Є. Ільїна, А. Маслоу, А. Матюшкіна, О. Виготський, C. Рубінштейн та інші довели, що мотивація, як рушійна сила діяльності людини, посідає значне місце у структурі особистості. Одні дослідники визначають мотив як предмет задоволення потреби, інші - як спонукальну силу. Найбільш поширеною є думка, що мотивом діяльності є усвідомлена потреба [1, с. 216].

І. Войтович у своїх дослідженнях наголошує, що мотивація є регуляторним компонентом навчальної діяльності, який забезпечує високу результативність навчання унаслідок педагогічного впливу та прогнозує пізнавальну активність студентів і перетворює зовнішню регуляцію на саморегуляцію [2].

Вивчення професійної готовності неможливе без урахування особистісної направленості суб'єкта професійної діяльності. Тому, моделюючи готовність майбутніх педагогів дошкільної освіти до застосування STEM-технологій у вигляді його структури, ми передусім розглядаємо мотиваційноціннісний компонент. Основний зміст цього компонента складається у вмотивованості суб'єкта до перетворення об'єктів своєї діяльності з новими властивостями та якостями; у його прагненні до розвитку наукових знань про об'єкт діяльності; у потребі практичного використання методологічних підходів для вивчення об'єкта та його перетворень.

Ми виходимо з того, що під мотивом («мотив від лат. - спонукати, надавати руху) потрібно розуміти предметний зміст потреби, для задоволення якої суб'єкт здійснює активну, спрямовану діяльність», а «мотивація - спонукання до діяльності людини, пов'язана із задоволенням певних потреб як процес дії мотиву... » [10, с. 66].

Мотиваційно-ціннісний компонент, на думку О. Акімової, являє собою сукупність соціальних установок, мотивів, нахилів, інтересів, потреб, ціннісних орієнтацій і сорормованих психологічних властивостей, які визначають рівень розвитку мотиваційної сорери майбутніх педагогів до вирішення педагогічних проблем та спонукають здійснювати професійну діяльність, спрямовану на вирішення цих проблем [1, с. 146].

А. Маркова зазначає, що мотив у навчанні $\epsilon$ спрямованістю особистості на окремі сторони навчальної роботи, яка виражає внутрішнє ставлення особистості до роботи. Дослідниця поділяє мотиви навчальної діяльності на: 1) пізнавальні мотиви, що мають такі рівні: широкі пізнавальні мотиви (орієнтація на оволодіння новими знаннями), навчально-пізнавальні мотиви (орієнтація на засвоєння способів оволодіння знаннями, прийомів самостійної пізнавальної діяльності), мотиви самоосвіти (орієнтація на набуття додаткових знань і потім на побудову спеціальної програми самовдосконалення); 2) соціальні мотиви, які можуть мати такі рівні: широкі соціальні мотиви (обов'язок і відповідальність, розуміння соціальної значимості учіння), вузькі соціальні (прагнення зайняти певну позицію у стосунках з оточуючими, отримати їхнє схвалення), мотиви соціального співробітництва (орієнтація на різні способи взаємодії з іншими людьми) [4, с. 76].

Мотивація $€$ рушійною силою зовнішньої і внутрішньої активності суб'єкта та посідає провідне місце в структурі особистості [5].

Мотиваційна готовність до професійно-педагогічної діяльності передбачає наявність активної позиції з перетворення дійсності. Відповідно, «мотиваційна готовність до застосування STEMтехнологій» передбачає фрормування позитивного ставлення до впровадження STEM-технологій, наявність певних ціннісних орієнтацій, що базуються на знаннях із галузі STEM-освіти, переконаність у необхідності здійснення STEM-діяльності.

У нашому дослідженні мотиваційно-ціннісний компонент характеризується наявністю у майбутніх педагогів дошкільної освіти системи цінностей, інтересів, потреб і мотивів засвоєння змісту теоретичних та процесуально-методичних аспектів застосування STEM-технологій у професійній діяльності.

Отже, «мотиваційна готовність до застосування STEM-технологій» включає в себе: фрормування позитивної мотивації на здійснення STEM-освіти в професійній діяльності (професійний мотив); емоціонально-особистісний апарат професійної діяльності (комплекс особистісних властивостей, що впливають на мотиви професійної діяльності із забезпечення STEM-освіти учасників освіти).

Такий компонент готовності до професійнопедагогічної діяльності вважаємо за можливе співвіднести з такою характеристикою готовності до застосування STEM-технологій, як дієвість.

Дієвість представимо як «мотиваційну готовність до STEM-освіти», яка припускає спрямованість особистості на STEM-освіту, формування позитивної мотивації на STEM-діяльність.

Мотиваційна готовність до застосування STEMтехнологій передбачає ініціативність педагога, яка проявляється в прагненні до здійснення інноваційної діяльності, підприємливість і здатність до самостійних дій, спрямованих на всебічний розвиток особистості дитини. Таким чином, мотиваційну готовність до застосування STEM-технологій вважаємо за можливе співвіднести 3 ініціативністю педагога. Ініціативність передбачає: здійснення самоосвіти і підвищення професійно-педагогічної кваліфрікації з питань STEM-освіти; потребу педагога у творчому розвитку дітей; здатність спланувати й організувати власне дослідження в аспекті STEM-технологій.

Мотиваційний компонент, що виконує стимулюючу функцію, містить у своїй структурі ціннісні 
орієнтації та мотиви, сукупність яких відображає психологічну готовність до застосування STEMтехнологій у майбутній профресійній діяльності, а також відповідну установку на професійну діяльність, а саме:

1) ступінь сорормованості STEM-освітніх ціннісних орієнтацій;

2) самоаналіз особистості 3 позиції STEM діяльності;

3) особистісний сенс STEM діяльності;

Мотиваційно-ціннісний компонент готовності майбутніх педагогів до застосування STEMтехнологій у професійній діяльності включає в себе:

- усвідомлене розуміння актуальності STEMдіяльності майбутнього педагога дошкільної освіти;

- бажання оволодіти теорією і практикою STEM-освіти у дошкільних закладах;

- мотивацію на підвищення профресійної компетентності у галузі STEM-технологій;

- мотиваційну спрямованість особистості майбутнього педагога на застосування STEMтехнологій і усвідомлену потребу передати їі дітям, пізнавальний інтерес і прагнення до STEMдіяльності, пропаганду STEM-технологій в освітньому процесі;

- творчий підхід до пошуку раціональних засобів STEM-освіти, до впровадження в практику дошкільних заходів інноваційних педагогічних методів, засобів і прийомів навчання, виховання і розвитку дітей;

- ціннісне ставлення до оволодіння основами STEM-освіти як умови підвищення результативності професійної діяльності;

- інтерес до STEM-діяльності, прагнення самостійно ставити і досягати мети такої діяльності, до особистісного саморозвитку, професійного самовдосконалення, самореалізації.

Для визначення основних мотивів, що спонукають майбутніх педагогів дошкільної освіти до застосування STEM-технологій у професійній діяльності, нами проведено анкетування, в якому взяли участь 120 студентів фракультету дошкільної освіти Глухівського національного педагогічного університету імені Олександра Довженка та студентів навчально-наукового інституту педагогіки і психології Сумського державного педагогічного університету імені А.С. Макаренка.

За допомогою анкетування ми з'ясували, що найбільш вираженими мотивами є такі:

- розуміння перспектив саморозвитку в профеciї - 54,17\%;

- розвиток творчого мислення - 48, 33\%;

- інтелектуальний розвиток - 42,50\%;

- підвищення профресійної компетентності $40,83 \%$;

- мотив ігри і розваги - 26,67\%;
- досягнення нових педагогічних цілей $24,17 \%$

- соціальна відповідальність - 20,83\%.

Зміст провідних мотивів указує на усвідомленість вибору цієї профресії більшістю респондентів та розуміння перспектив подальшого професійного розвитку. У багатьох студентів спостерігається позитивне ставлення до діяльності, спрямованої одночасно на STEM-освіту та всебічний розвиток особистості дітей. Виявлялась упевненість, що така діяльність необхідна. Однак при цьому активність більшості майбутніх педагогів у набутті і накопиченні досвіду відповідної діяльності залишалася низькою.

Відповіді на питання анкети показують, що майбутні фрахівці дошкільної освіти розуміють роль STEM-технологій для своєї профресійної діяльності. Водночас вони не володіють достатньою мірою засобами STEM-технологій, оскільки недостатньо отримують відповідні знання в процесі профресійної підготовки, хоча вважають, що дисципліни базового циклу мають досить вагомий вплив для їхньої STEM-освіти.

Серед найменш актуальних мотивів зазначена висока відповідальність вибраної професії, що вказує на невпевненість майбутніх педагогів дошкільної освіти у власній готовності до застосування STEM-технологій у професійній діяльності.

Висновки. Готовність майбутніх педагогів дошкільної освіти до застосування STEMтехнологій у професійній діяльності ми розуміємо як інтегральну, професійну й особистісну якість, що дає змогу забезпечити раціональну і досконалу професійну діяльність із дітьми дошкільного віку, основою якої є методологічна єдність природничих, технічних і соціально-гуманітарних наук, що проявляється у застосуванні спільного математичного апарату, інформаційно-комунікаційних технологій, моделювання та міждисциплінарної взаємодії.

3 огляду на те, що мотивація є регулятором професійної діяльності та впливає наїї продуктивність, провідним компонентом у структурі готовності майбутніх педагогів дошкільної освіти до застосування STEM-технологій у професійній діяльності ми виділяємо мотиваційно-ціннісний компонент.

Мотиваційно-ціннісний компонент передбачає фрормування потреб, інтересів, професійних цінностей, що пробуджує у майбутніх педагогів дошкільної освіти відповідальне ставлення до професійної діяльності, мотивує до засвоєння інноваційних технологій, профресійно спрямовує і слугує орієнтиром у професійному саморозвитку.

Мотиваційний компонент утворює основу для реалізації інших структурних компонентів професійної готовності, тому що саме він характеризує смислову спрямованість особистості майбутнього педагога дошкільної освіти на STEM-освіту та STEM-діяльність. 
Перспективи подальших досліджень ми вбачаємоувизначенніта обґрунтуванні інших компонентів структури готовності майбутніх педагогів дошкільної освіти до застосування STEM-технологій у професійній діяльності, а саме: когнітивного, діяльнісного і рефлексивного.

\section{БІБЛІОГРАФІЧНИЙ СПИСОК:}

1. Акімова О.В. Теоретико-методичні засади формування творчого мислення майбутнього вчителя в умовах університетської освіти : дис. ... доктора пед. наук : 13.00.04. Вінниц. держ. пед. ун-т ім. М. Коцюбинського. Вінниця, 2011. 534 с.

2. Войтович І.С. Мотивація навчання майбутніх учителів у процесі їх підготовки до профессійної діяльності. Наукові записки. Серія: Педагогіка. 2014. № 4. C. 47-59.

3. Малишевська В.О. Проблема використання STEM-технологій у теорії і практиці професійної підготовки майбутніх педагогів дошкільної освіти. Вісник Глухівського національного університету імені Олександра Довженка. Педагогічні науки. 2019. Вип. 3 (41). С. 219-228.

4. Маркова А.К. Психология профессионализма. Москва : Междун. гуман. фонд «Знание», 1996. 309 c.
5. Нечипоренко М. Мотивація як ключовий фрактор майбутніх учителів іноземних мов до профресійно особистісного саморозвитку. Наукові записки. Серія: Педагогіка. 2017. № 2. C. 102-109.

6. Нова українська школа : порадник для вчителя / за ред. Н.М. Бібік. Київ : ТОВ «Видавничий дім «Плеяда», 2017. 206 с.

7. Патрикеєва О., Лозова О., Горбенко С. STEMосвіта: умови впровадження у навчальних закладах України. Управління освітою. 2017. № 1. C. 28-31.

8. Пантюк T.I. Суспільно-педагогічні детермінанти підготовки дітей до школи в Україні: теорія і практика (1945-2017 рр.) : дис. ... докт. пед. наук : 13.00.01. Дрогоб. держ. пед. ун-т ім. Івана Франка; Житомир. держ. ун-т ім. Івана Франка, 2018. 544 c.

9. Бєлєнька Г.В. Підготовка майбутніх вихователів до роботи 3 дітьми дошкільного віку: компетентнісний підхід : монографія / за заг. ред. Г.В. Бєлєнької, О.А. Половіної. Умань : ВПЦ «Візаві», 2015. 208 с.

10. Сучасний тлумачний словник: 65000 слів / за заг. ред. В.В. Дубічинського. Харків : Школа, 2012. $100 \mathrm{c}$. 